\title{
JESYA
}

JURNAL EKONOMI \& EKONOMI SYARIAH

Jurnal Ekonomi \& Ekonomi Syariah Vol 3 No 2, Juni 2020

E-ISSN : 2599-3410 |P-ISSN : 2614-3259

DOI : https://doi.org/10.36778/jesya.v3i2.185

\section{Analisis Pengembangan Ekonomi Masyarakat Melalui Sektor Pertanian di Kab. Padang Lawas Utara}

\author{
Marita \\ Universitas Sumatera Utara \\ maritadamanik@gmail.com
}

\begin{abstract}
Abstrak Faktor terpenting yang mempengaruhi produktivitas pertanian adalah mutu benih, lahan pertanian dan pemasaran hasil panen. Tingkat pendapatan petani secara umum dipengaruhi oleh beberapa komponen yaitu : jumlah produksi, harga jual, dan biaya- biaya yang dikeluarkan petani dalam pertaniannya. Ini berarti bahwa perhatian pemerintah terhadap sektor pertanian merupakan usaha untuk memperbaiki taraf kehidupan sebagian besar penduduk yang tergolong miskin. Pertanian dan perkebunan merupakan salah satu komoditi yang mempunyai prospek cerah guna menambah pendapatan para petani. Hal tersebut dapat memberi motivasi tersendiri bagi petani untuk lebih mengembangkan dan meningkatkan produksinya dengan harapan agar pada saat panen usaha memperoleh hasil penjualan tinggi guna memenuhi kebutuhannya. Namun kadang kala dalam kenyataannya berbicara lain. Ketika saat panen tiba, hasil melimpah tetapi harga mendadak turun, dan lebih parah lagi jika hasil produksi yang telah diprediksikan jauh melenceng dari jumlah produksi yang dihasilkan, produksi minim, harga rendah dan tidak menentu membuat petani kadang merasa kecewa bahkan patah semangat untuk tetap mengembangkan usaha pertaniannya. Hal ini disebabkan karena setiap kegiatan pengolahan lahan pertanian mutlak petani mengeluarkan biaya untuk kegiatan produksi, mulai dari pengadaan bibit, pupuk, pengolahan, pestisida dan biaya lainnya yang tidak terduga
\end{abstract}

\section{Kata Kunci Sektor Pertanian, Ekonomi Potensial dan Pengaruh faktor-faktor}

\section{PENDAHULUAN}

Pembangunan nasional dewasa ini diprioritaskan pada bidang perekonomian sehingga pemerintah selalu berusaha untuk menerapkan kebijaksanaan dalam peningkatan hasil produksi pertanian. Apalagi negara kita terkenal dengan negara agraris yang mempunyai areal pertanian yang cukup luas, dengan sumber daya alam yang masih sangat perlu digali dan dimanfaatkan untuk pemenuhan kebutuhan manusia. Disamping hal tersebut Indonesia adalah negara agraris. Banyak wilayah di Indonesia yang memanfaatkan lahan sebagai mata pencaharian utama melalui bidang pertanian.

Indonesia sepertinya kehilangan predikat sebagai Negara Agraris. Dalam rentang waktu 1999 - 2016 Bank Indonesia mencatat penurunan pangsa sektor pertanian terhadap Produk Domestik Bruto (PDB) dari 22,09\% menjadi hanya 13,45\% pada tahun 2016 (HPDKI 04 januari 2017). Sasaran utama pembangunan pertanian dewasa ini adalah peningkatan produksi pertanian dan pendapatan petani, karena itu kegiatan disektor pertanian diusahakan agar dapat berjalan lancar dengan peningkatan produk pangan baik melalui intensifikasi, ekstensifikasi, dan diversifikasi pertanian yang diharapkan dapat memperbaiki taraf hidup petani, memperluas lapangan pekerjaan bagi golongan masyarakat yang masih tergantung pada sektor pertanian.

Kegiatan pertanian yang menyerap tenaga kerja hendaknya menjadi perhatian tenaga kerja 
merupakan salah satu faktor produksi yang penting. Tenaga kerja dapat mempengaruhi besarnya output dan permintaan akhir Oleh sebab itu, permintaan akhir dapat memberikan dampak terhadap kebutuhan tenaga kerja (Haris, Sarma dan Falatehan, 2017).

Tingkat pendapatan petani secara umum dipengeruhi oleh beberapa komponen yaitu: jumlah produksi, harga jual, dan biaya-biaya yang dikeluarkan petani dalam pertaniannya. Ini berarti bahwa perhatian pemerintah terhadap sektor pertanian merupakan usaha untuk memperbaiki taraf kehidupan sebagian besar penduduk yang tergolong miskin. Pertanian dan perkebunan merupakan salah satu komoditi yang mempunyai prospek cerah guna menambah pendapatan para petani. Hal tersebut dapat memberi motivasi tersendiri bagi petani untuk lebih mengembangkan dan meningkatkan produksinya dengan harapan agar pada saat panen usaha memperoleh hasil penjualan tinggi guna memenuhi kebutuhannya. Namun kadang kala dalam kenyataannya berbicara lain.

Ketika saat panen tiba, hasil melimpah tetapi harga mendadak turun, dan lebih parah lagi jika hasil produksi yang telah diprediksikan jauh melenceng dari jumlah produksi yang dihasilkan, produksi minim, harga rendah dan tidak menentu membuat petani kadang merasa kecewa bahkan patah semengat untuk tetap mengembangkan usaha pertaniannya. Hal ini disebabkan karena setiap kegiatan pengolahan sawah mutlak petani mengeluarkan biaya untuk kegiatan produksi, mulai dari pengadaan bibit, pupuk, pengolahan, pestisida dan biaya lainnya yang tidak terduga.

Langkah pemerintah dalam meningkatkan kualitas pertanian adalah dengan melakukan strategi pembangunan alternatif dengan cara misalnya melalui pengembangan inftrastruktur sarana dan prasarana di pertanian, misalnya dengan cara pembangunan saluran air untuk pengairan yang lebih baik dan menyiapkan lahan untuk meningkatkan hasil output di pertanian. Selain itu pemerintah juga bisa menciptakan pengembangan produk pertanian sehingga dapat menciptakan surplus yang lebih tinggi (Widyawati, 2017).

Model pembangunan pertanian Indonesia dari dulu hingga saat sekarang, sebagian besar merupakan penggulangan sejarah pelaksanaan kebijakan pembangunan di masa lalu. Perhatian lebih banyak diberikan pada proses bagian hulu seperti akses sumber daya lahan, penyediaan berbagai sarana produksi dan teknik produksi. Idiologi penyediaan pangan adalah pangan murah. Kebijakan pembangunan pertanian di Indonesia dari masa kemasa tidak menunjukkan perubahan yang berarti. Ditemukan adanya kebijakan pembangunan pertanian setelah kemerdekaan yang menggulang kebijakan pada zaman kolonial. Perhatian yang serius terkait aspek hilir yaitu kebijakan harga yang layak masih sangat terbatas atau bahkan terabaikan. Persoalan pertanian tidak dapat dipandang sebagai persoalan sektoral, tetapi harus ditempatkan sebagai persoalan negara (Gevisioner, Febrimansyah, Ifdal dan Tarumun, 2017)

Pemerintah daerah dalam upaya meningkatkan pembangunan ekonomi khususnya mengenai pengembangan sub sektor tanaman pangan agar tetap berdasarkan potensi yang dimiliki, dengan melalui arah kebijakan yang tepat, yaitu dengan pembangunan sentra produksi dan sentra industri pengolahan sehingga melalui kebijakan tersebut dapat memberikan nilai tambah bagi hasil-hasil produksi pertanian .

Dalam meningkatkan potensi pertanian diperlukan campur tangan pemerintah terkait implikasi kebijakan yang perlu diterapkan di kabupaten/kota dengan basis pertanian bisa berupa peningkatan infrastruktur untuk memfasilitasi hubungan investor dengan daerah terkait, dukungan dan bantuan dari pemerintah, baik itu berupa modal maupun pendidikan, pelatihan dan penyuluhan, menyediakan lembaga permodalan, serta kebijakan lainnya yang mendukung percepatan pembangunan sektor pertanian (Novitasari, Sulistyowati dan Karmana, 2019)

Untuk memperoleh pendapatan yang memuaskan petani, maka petani dituntut kecermatannya dalam mempelajari perkembangan harga sebagai solusi dalam menentukan 


\section{JESYA}

JURNAL EKONOMI \& EKONOMI SYARIAH

Jurnal Ekonomi \& Ekonomi Syariah Vol 3 No 2, Juni 2020

E-ISSN : 2599-3410 |P-ISSN : 2614-3259

DOI : https://doi.org/10.36778/jesya.v3i2.185

pilihan, apakah ia memutuskan untuk menjual atau menahan hasil produksinya. Namun bagi petani yang secara umumnya menggantungkan hidupnya dari bertani, maka mereka senantiasa tidak memiliki kemampuan untuk menahan hasil panen kecuali sekedar untuk konsumsi seharihari dan membayar biaya produksi yang telah dikeluarkan.

Sektor pertanian, kehutanan, dan perikanan tumbuh 4,3 persen (YoY), lebih tinggi dibandingkan periode yang sama tahun sebelumnya (3,8 persen, YoY). Produksi sektor ini secara umum meningkat kecuali produksi tanaman pangan dan kehutanan yang masing masing terkontraksi sebesar 1,0 dan 0,2 persen (YoY). Penurunan produksi tanaman pangan disebabkan oleh cuaca ekstrim, musim kemarau yang lebih panjang dari tahun sebelumnya. Sementara itu, produksi tanaman perkebunan dan peternakan meningkat tajam menjadi 5,2 dan 7,9 persen. Pertumbuhan produksi tanaman perkebunan didorong oleh meningkatnya produksi kelapa sawit (Bappenas, 2019).

Pertanian merupakan kegiatan dalam usaha mengembangkan (reproduksi) tumbuhan dan hewan dengan maksud supaya tumbuh lebih baik untuk memenuhi kebutuhan manusia, misalnya bercocok tanam, beternak dan melaut. Pertanian juga sebagai jenis usaha atau kegiatan ekonomi berupa penanaman tanaman atau usahatani (pangan, hortikultura, perkebunan dan kehutanan), peternakan (beternak) dan perikanan (budidaya dan menangkap) (Rahim dan Hastuti, 2007). Sektor pertanian terdiri atas sub sektor, yaitu: (1) Sub sektor tanaman pangan, (2) Sub sektor hortikultura, (3) Sub sektor perkebunan, (4) Sub sektor perikanan, (5) Sub sektor peternakan, dan (6) Sub sektor kehutanan (Rahim dan Hastuti, 2007).

Sub sektor perkebunan dan pertanian mempunyai peluang yang sangat besar untuk dijadikan andalan ekspor. Pembangunan dibidang perkebunan diarahkan untuk lebih mempercepat laju pertumbuhan produksi baik dari perkebunan besar, swasta maupun perkebunan negara. Mendukung pembangunan industri, serta meningkatan pemanfaatan dan kelestarian sumber daya alam (SDA) berupa tanah dan air. Peran sektor perkebunan yang demikian besar bagi peningkatan pemanfaatan petani dan penyediaan bahan baku untuk industri dalam negeri serta sebagai sumber devisa negara (Arifin, 2001).

\section{LANDASAN TEORI}

Potensial areal pertanian dan perkebunan di Kab. Padang Lawas masih memiliki tingkat yang tinggi untuk di kembangkan oleh karena itu hal ini berimplikasi terhadap daya ekonomi masyarakat kab. Padang Lawas. Menurut data BPS Padang Lawas pada s/d tahun 2015 ada beberapa bentuk produksi perkebunan yang ada di Kab. Padang Lawas adalah; karet, kelapa sawit, kopi robusta, kelapa, kakao, cengkeh, kayu manis, Nilam,Kemiri, Tembakau dan Aren. dengan total luas lahan masing- masing komoditas yang ada dari data Badan Pusat Statistik (BPS) Kab. Padang Lawas.

Dalam hal ini terdapat peranan petani di Indonesia tercatat sebagai devisa yang cukup besar bagi negara. Namun, disamping itu pertanian juga merupakan sumber kehidupan bagi sebagian besar penduduknya. Dengan bertambahnya kebutuhan dan meningkatnya teknologi, maka petani dihadapkan dengan pemilihan alternatif yang terbaik (yang paling efisien) guna memanfaatkan sumber daya yang terbatas jumlahnya. Untuk menangani hal ini, dibutuhkan pengelolaan yang baik melalui keterampilan yang ulet dan berdasarkan perhitungan yang berencana. Disinilah timbul peranan pertanian terpadu yang merupakan penjumlahan dari seluruh kegiatan yang berhubungan dengan produksi dan distribusi hasil pertanian. Menurut Kartasasmita strategi pengembangan ekonomi masyarakat yang lebih kuat perlu diarahkan untuk mendorong percepatan struktural (structural transformation) untuk memperkuat kedudukan dan peran ekonomi rakyat dalam perekonomian nasional. Transformasi struktural ini meliputi proses perubahan ekonomi tradisional menjadi ekonomi modern, ekonomi lemah menjadi ekonomi yang tangguh, ekonomi subsistem ke ekonomi pasar, dari ketergantungan kepada kemandirian. 


\section{JESYA}

JURNAL EKONOMI \& EKONOMI SYARIAH

Jurnal Ekonomi \& Ekonomi Syariah Vol 3 No 2, Juni 2020

E-ISSN : 2599-3410 |P-ISSN : 2614-3259

DOI : https://doi.org/10.36778/jesya.v3i2.185

Di bawah ini adalah strategi pengembangan ekonomi masyarakat diantaranya adalah:

1. Peningkatan akses kepada asset produksi (productive assets).

2. Memperkuat posisi transaksi dan kemitraan usaha ekonomi rakyat. Sebagai produsen dan penjual, posisi dan kekuatan rakyat dalam perekonomian sangatlah lemah.

3. Meningkatkan pelayanan pendidikan dan kesehatan dalam rangka meningkatkan kualitas sumber daya manusia.

4. Kebijaksanaan pengembangan industri rakyat yang mengarah pada penguatan industri rakyat.

5. Kebijakan ketenagakerjaan yang merangsang tumbuhnya tenaga kerja mandiri sebagai wirausaha kecil dan menengah yang kuat dan saling menunjang

6. Pemerataan pembangunan antar daerah, yaitu memberikan kesempatan yang lebih besar pada ekonomi rakyat di daerah yang terbelakang untuk berkembang.

7. Adanya perangkat peraturan perundang-undangan yang memadai untuk melindungi dan mendukung pengembangan ekonomi rakyat yang ditujukan khusus untuk kepentingan rakyat kecil.

Luas Tanaman Perkebunan Menurut Jenis Tanaman di Kabupaten Padang Lawas, 2007-2015

\begin{tabular}{|c|c|c|c|c|c|c|c|c|c|}
\hline \multirow[b]{2}{*}{ Jenis Tanaman } & \multicolumn{9}{|c|}{ Luas Tanaman } \\
\hline & $\begin{array}{c}2007 \\
\text { (ha) }\end{array}$ & $\begin{array}{c}2008 \\
\text { (ha) }\end{array}$ & $\begin{array}{c}2009 \\
\text { (ha) }\end{array}$ & $\begin{array}{c}2010 \\
\text { (ha) }\end{array}$ & $\begin{array}{c}2011 \\
\text { (ha) }\end{array}$ & $\begin{array}{c}2012 \\
\text { (ha) }\end{array}$ & $\begin{array}{c}2013 \\
\text { (ha) }\end{array}$ & $\begin{array}{c}2014 \\
\text { (ha) }\end{array}$ & $\begin{array}{c}2015 \\
\text { (ha) }\end{array}$ \\
\hline Karet & $\begin{array}{c}73 \\
581,75 \\
\end{array}$ & 6216 & 6175 & 11354 & $\begin{array}{c}11 \\
728,68 \\
\end{array}$ & $\begin{array}{c}12 \\
011,23 \\
\end{array}$ & $\begin{array}{c}12 \\
011,23 \\
\end{array}$ & $\begin{array}{c}12 \\
011,23 \\
\end{array}$ & $\begin{array}{c}17 \\
182,88 \\
\end{array}$ \\
\hline Kelapa Sawit & $\begin{array}{c}60 \\
006,65 \\
\end{array}$ & $\begin{array}{c}16 \\
358 \\
\end{array}$ & $\begin{array}{c}17 \\
300 \\
\end{array}$ & $\begin{array}{c}31 \\
442,1 \\
\end{array}$ & $\begin{array}{c}32 \\
385,36 \\
\end{array}$ & $\begin{array}{c}32 \\
540,42 \\
\end{array}$ & $\begin{array}{c}32 \\
540,42 \\
\end{array}$ & $\begin{array}{c}32 \\
540,42 \\
\end{array}$ & $\begin{array}{c}41 \\
480,09 \\
\end{array}$ \\
\hline Kopi Robusta & 3815 & 117 & 137 & 984 & 1033,62 & 832,53 & 832,53 & 832,53 & 860,06 \\
\hline Kelapa & 2509,80 & 482 & 482 & 702,2 & 723,27 & 744,53 & 744,53 & 744,53 & 629,05 \\
\hline Kakao & 4773,50 & 64 & 64 & 186,55 & 192,15 & 198,40 & 198,40 & 198,40 & $\begin{array}{c}1 \\
081,42\end{array}$ \\
\hline Cengkeh & 24,50 & - & - & - & - & - & - & - & - \\
\hline Kayu Manis & 1853 & 415 & 240 & - & - & - & - & - & 821,00 \\
\hline Nilam & 1130 & 20 & 16 & - & - & - & - & - & - \\
\hline Kemiri & 689 & 36,5 & 36,5 & - & - & 35,50 & 35,50 & 35,50 & 127,55 \\
\hline Tembakau & 7 & 3 & 19,5 & - & - & - & - & - & 75,00 \\
\hline Aren & 999,80 & 19 & 16 & 340,85 & 352,10 & 360,39 & 360,39 & 360,39 & 48,55 \\
\hline Pala & 10,50 & - & - & - & - & - & - & - & - \\
\hline Kapuk & 212,27 & - & - & - & - & - & - & - & - \\
\hline Pinang & 394 & 58 & 58 & 18,77 & 9,00 & 21,59 & 21,59 & 21,59 & 141,13 \\
\hline Jahe & - & - & 4 & - & - & - & - & - & - \\
\hline Kapulaga & 3,50 & - & - & - & - & - & - & - & - \\
\hline Jambu Mente & 5,54 & - & - & - & - & - & - & - & - \\
\hline Jarak & 55,65 & - & - & - & - & - & - & - & - \\
\hline
\end{tabular}

Sumber: Dinas Kehutanan dan Perkebunan Kabupaten Padang Lawas

Produksi Tanaman Perkebunan Menurut Jenis Tanaman di Kabupaten Padang Lawas, 2007-2015

\section{Total Produksi}


DOI : https://doi.org/10.36778/jesya.v3i2.185

\begin{tabular}{|l|c|c|c|c|c|c|c|c|c|c|}
\multirow{2}{*}{$\begin{array}{c}\text { Jenis } \\
\text { Tanaman }\end{array}$} & $\mathbf{2 0 0 7}$ & $\mathbf{2 0 0 8}$ & $\mathbf{2 0 0 9}$ & $\mathbf{2 0 1 0}$ & $\mathbf{2 0 1 1}$ & $\mathbf{2 0 1 2}$ & $\mathbf{2 0 1 3}$ & $\mathbf{2 0 1 4}$ & $\mathbf{2 0 1 5}$ \\
\cline { 2 - 11 } & (ton) & (ton) & (ton) & (ton) & (ton) & (ton) & (ton) & (ton) & (ton) \\
\hline Karet & 21983 & 8248 & 7259,9 & $\begin{array}{c}3 \\
504,65\end{array}$ & $\begin{array}{c}3 \\
623,81\end{array}$ & $\begin{array}{c}3 \\
746,25\end{array}$ & $\begin{array}{c}3 \\
746,25\end{array}$ & $\begin{array}{c}3 \\
746,25\end{array}$ & $\begin{array}{c}33 \\
388,98\end{array}$ \\
\hline $\begin{array}{c}\text { Kelapa } \\
\text { Sawit }\end{array}$ & 278 & 135 & 141 & 85 & 88 & 89 & 89 & 89 & 622 \\
\hline $\begin{array}{c}\text { Kopi } \\
\text { Robusta }\end{array}$ & 12194 & 35,1 & 41,1 & 160,05 & 214,47 & 287,39 & 287,39 & 287,39 & $\begin{array}{c}4 \\
295,66\end{array}$ \\
\hline Kelapa & 28946 & 3666 & 3666 & 362,65 & 374,98 & 385,75 & 385,75 & 385,75 & 1 \\
000 & $000^{*}$ & 820 & 738,31 & 653,41 & 419,88 & 419,88 & 419,88 & 258,17 \\
\hline Kakao & 13506 & 15,8 & 15,8 & 47,10 & 48,70 & 48,70 & 48,70 & 48,70 & 509,41 \\
\hline Cengkeh & 1625 & - & - & - & - & - & - & - & - \\
\hline Kayu Manis & 4989 & 704 & 625 & - & - & - & - & - & 2 \\
\hline Nilam & 0,22 & 0,4 & 0,3 & - & - & - & - & - & - \\
\hline Kemiri & 4426 & 95,7 & 95,7 & - & - & 92,5 & 92,5 & 92,5 & 2 \\
\hline Tembakau & 1,60 & 12,0 & 60,0 & - & - & - & - & - & 499,83 \\
\hline Aren & 43,463 & 125,0 & 105 & 33,50 & 34,64 & 34,99 & 34,99 & 34,99 & 88,8 \\
\hline Pinang & 10925 & 603 & 603 & 4,50 & 6,50 & 6,50 & 6,50 & 6,50 & 448,42 \\
\hline Jahe & - & - & 10 & - & - & - & - & - & - \\
\hline
\end{tabular}

Sumber : Dinas Kehutanan dan Perkebunan Kabupaten Padang Lawas

Dengan produksi pada tahun 2015 adalah sebagai berikut:

Produksi Tanaman Perkebunan Menurut Kecamatan dan Jenis Tanaman di Kabupaten Padang Lawas Utara (Ton) 2015

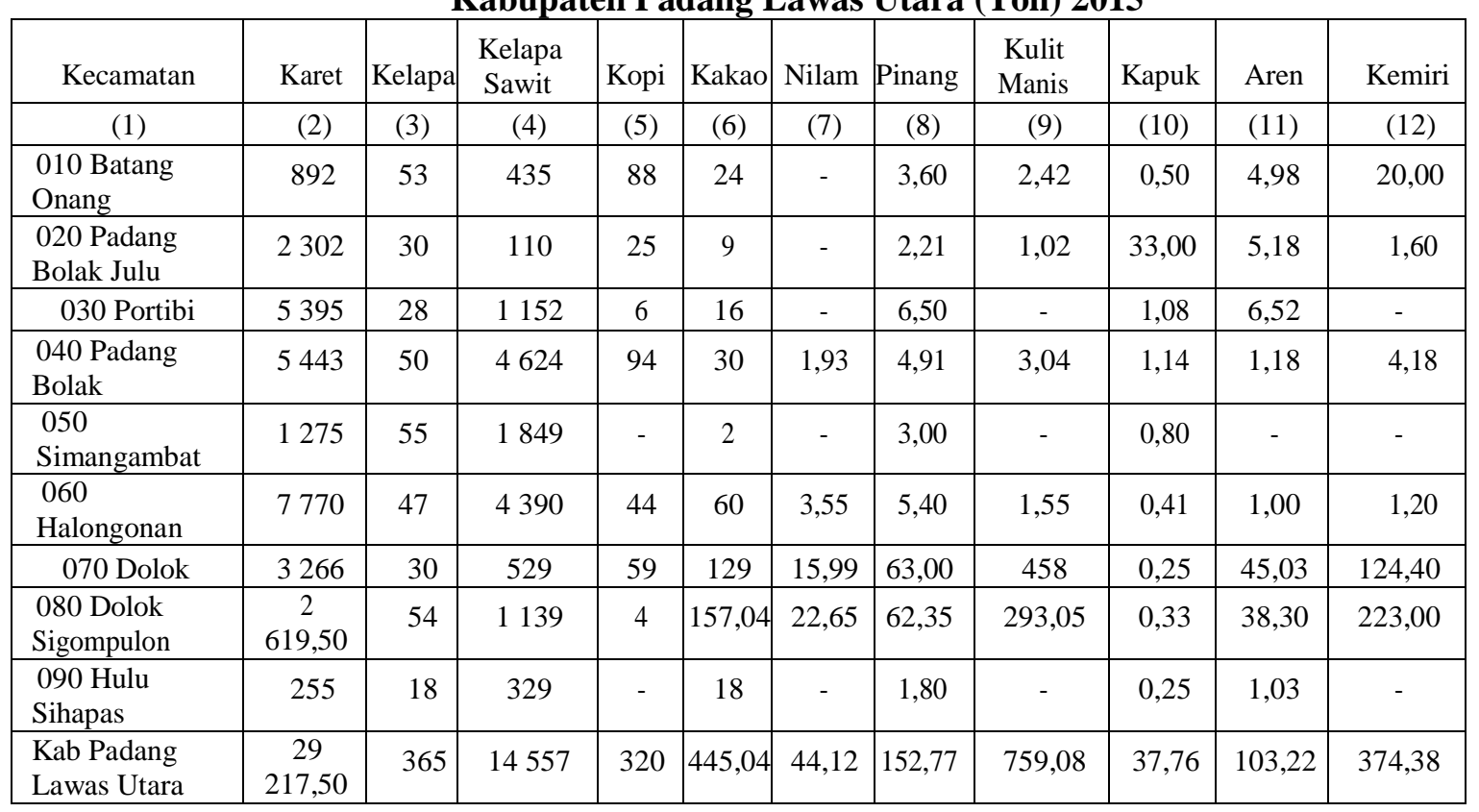


DOI : https://doi.org/10.36778/jesya.v3i2.185

\begin{tabular}{|c|c|c|c|c|c|c|c|c|c|c|c|}
\hline 2014 & 29 & 357 & 66 & 781 & 430,00 & 65,15 & 149,07 & 759,00 & 37,67 & 242,80 & 374,36 \\
\hline
\end{tabular}

Sumber: Dinas Kehutanan dan Perkebunan Kabupaten Padang Lawas Utara

Adanya penurunan jumlah panen pada tanaman kelapa sawit di kab. Padang Lawas Utara misalnya perlu dicarikan penyebab kenapa hal itu terjadi sedangkan lahan untuk yang ditanami perkebunan kelapa sawit sebenarnya ada penambahan dari segi luasannya. Adapun untuk jenis tanaman pertanian dan hortikultura pada tahun 2014 dan 2015 adalah sebagai berikut:

Luas Panen, Produksi dan Produktivitas Jagung dan Kedelai Menurut Kecamatan di Kabupaten Padang Lawas Utara 2015

\begin{tabular}{|c|c|c|c|c|c|c|}
\hline \multirow[b]{2}{*}{ Kecamatan } & \multicolumn{3}{|c|}{ Jagung } & \multicolumn{3}{|c|}{ Kedelai } \\
\hline & $\begin{array}{l}\text { Luas } \\
\text { Panen } \\
\text { (Bersih) } \\
\text { (Ha) }\end{array}$ & $\begin{array}{l}\text { Produksi } \\
\text { (Ton) }\end{array}$ & $\begin{array}{r}\text { Produktivita } \\
\mathrm{s}(\mathrm{Kw} / \mathrm{Ha})\end{array}$ & $\begin{array}{c}\text { Luas } \\
\text { Panen } \\
\text { (Bersih) } \\
(\mathrm{Ha})\end{array}$ & $\begin{array}{l}\text { Produksi } \\
\text { (Ton) }\end{array}$ & $\begin{array}{r}\text { Produktivita } \\
\mathrm{s}(\mathrm{Kw} / \mathrm{Ha})\end{array}$ \\
\hline (1) & (2) & (3) & (4) & (5) & (6) & (7) \\
\hline 010 Batang Onang & 7 & 32,90 & 47 & 75 & 82,50 & 11 \\
\hline $\begin{array}{l}\text { 020 Padang Bolak } \\
\text { Julu }\end{array}$ & 18 & 95,40 & 53 & 202 & 262,60 & 13 \\
\hline 030 Portibi & 47 & 244,40 & 52 & 47 & 51,70 & 11 \\
\hline 040 Padang Bolak & 18 & 100,80 & 56 & 61 & 73,20 & 12 \\
\hline 050 Simangambat & 20 & 96,00 & 48 & 62 & 62,00 & 10 \\
\hline 060 Halongonan & 14 & 71,40 & 51 & 57 & 74,10 & 13 \\
\hline 070 Dolok & 8 & 36,80 & 46 & 31 & 37,20 & 12 \\
\hline $\begin{array}{l}080 \text { Dolok } \\
\text { Sigompulon }\end{array}$ & - & - & - & 35 & 35,00 & 10 \\
\hline 090 Hulu Sihapas & 15 & 72,00 & 48 & 26 & 31,20 & 12 \\
\hline $\begin{array}{l}\text { Kab Padang } \\
\text { Lawas Utara }\end{array}$ & 147 & 749,70 & 50,13 & 596 & 709,50 & 11,56 \\
\hline 2014 & 97 & 423,50 & 43,66 & 261 & 258,13 & 9,89 \\
\hline 2013 & 735 & $\begin{array}{c}3 \\
497,00\end{array}$ & 46,18 & 22 & 24 & 11,17 \\
\hline
\end{tabular}

Sumber: Dinas Pertanian dan Tanaman Pangan Kabupaten Padang Lawas Utara

\section{Luas Panen, Produksi dan Produktivitas Ubi Kayu dan Ubi Jalar Menurut} Kecamatan di Kabupaten Padang Lawas Utara 2015

\begin{tabular}{|c|c|c|c|c|c|c|}
\hline \multirow[b]{2}{*}{ Kecamatan } & \multicolumn{3}{|c|}{ Ubi Kayu } & \multicolumn{3}{|c|}{ Ubi Jalar } \\
\hline & $\begin{array}{l}\text { Luas } \\
\text { Panen } \\
\text { (Ha) }\end{array}$ & $\begin{array}{l}\text { Produksi } \\
\text { (Ton) }\end{array}$ & $\begin{array}{l}\text { Produktivit } \\
\text { as } \\
\text { (Kw/Ha) }\end{array}$ & $\begin{array}{l}\text { Luas } \\
\text { Panen } \\
\text { (Ha) }\end{array}$ & $\begin{array}{l}\text { Produksi } \\
\text { (Ton) }\end{array}$ & $\begin{array}{l}\text { Produktivit } \\
\text { as } \\
\text { (Kw/Ha) }\end{array}$ \\
\hline (1) & (2) & (3) & (4) & (5) & (6) & (7) \\
\hline $\begin{array}{l}010 \\
\text { Batang } \\
\text { Onang }\end{array}$ & - & - & - & - & - & - \\
\hline $\begin{array}{l}\text { 020 Padang } \\
\text { Bolak Julu }\end{array}$ & 23 & $\begin{array}{c}2 \\
783,00\end{array}$ & 121,00 & - & - & - \\
\hline 030 Portibi & 33 & $\begin{array}{c}6 \\
619,80\end{array}$ & 200,60 & 5 & 651,50 & 130,30 \\
\hline
\end{tabular}


DOI : https://doi.org/10.36778/jesya.v3i2.185

\begin{tabular}{|c|c|c|c|c|c|c|}
\hline $\begin{array}{l}\text { 040 Padang } \\
\text { Bolak }\end{array}$ & 4 & 763,20 & 190,80 & 3 & 362,10 & 120,70 \\
\hline $\begin{array}{l}050 \\
\text { Simangambat }\end{array}$ & 76 & 16765,60 & 220,60 & 8 & 886,40 & 110,80 \\
\hline $\begin{array}{l}060 \\
\text { Halongonan }\end{array}$ & 16 & 3204,80 & 200,30 & - & - & - \\
\hline 070 Dolok & 34 & 6480,40 & 190,60 & 22 & 2648,80 & 120,40 \\
\hline $\begin{array}{l}\text { 080 Dolok } \\
\text { Sigompulon }\end{array}$ & 2 & 340,80 & 170,40 & 1 & 110,54 & 110,54 \\
\hline $\begin{array}{l}090 \\
\text { Hulu } \\
\text { Sihapas }\end{array}$ & 2 & 360,40 & 180,20 & - & - & - \\
\hline $\begin{array}{l}\text { Kab Padang } \\
\text { Lawas Utara }\end{array}$ & 190 & 37318,00 & 184,31 & 39 & 4659,34 & 118,55 \\
\hline 2014 & 158 & 4433,64 & 280,61 & 41 & 519,84 & 126,79 \\
\hline 2013 & 165 & 1908,00 & 104,53 & 26 & 232 & 89,72 \\
\hline
\end{tabular}

Sumber: Dinas Pertanian dan Tanaman Pangan Kabupaten Padang Lawas Utara

Produksi Buah-Buahan Menurut Kecamatan dan Jenis Buah di Kabupaten

Padang Lawas Utara (Ton) 2015

\begin{tabular}{|c|c|c|c|c|c|c|c|}
\hline Kecamatan & $\begin{array}{c}\text { Mangg } \\
\text { a }\end{array}$ & Durian & Jeruk & Duku & $\begin{array}{c}\text { Pepay } \\
\text { a }\end{array}$ & $\begin{array}{c}\text { Manggi } \\
\mathrm{s}\end{array}$ & $\begin{array}{c}\text { Lainny } \\
\text { a }\end{array}$ \\
\hline (1) & (2) & (3) & (4) & (5) & (6) & (7) & (8) \\
\hline $\begin{array}{l}010 \\
\text { Batang } \\
\text { Onang }\end{array}$ & 29,70 & 12,50 & - & - & 16,40 & - & - \\
\hline $\begin{array}{l}\text { 020 Padang } \\
\text { Bolak Julu }\end{array}$ & 46,25 & 154,50 & - & 15,50 & 19,20 & - & - \\
\hline 030 Portibi & 104,00 & 3,60 & - & - & 35,00 & - & - \\
\hline $\begin{array}{l}\text { 040 Padang } \\
\text { Bolak }\end{array}$ & 158,55 & 86,90 & 0,70 & 58,10 & 97,60 & 2,30 & - \\
\hline $\begin{array}{l}\text { 050 } \\
\text { Simangamba } \\
\mathrm{t}\end{array}$ & - & 7,90 & - & 52,30 & - & 5,90 & - \\
\hline \begin{tabular}{l|}
060 \\
Halong \\
Eonan
\end{tabular} & 748,00 & 22,50 & - & 66,50 & 31 & 224,50 & - \\
\hline 070 Dolok & 96,75 & 220,00 & - & 304,70 & 41,70 & 116,20 & - \\
\hline $\begin{array}{c}\text { 080 Dolok } \\
\text { Sigompulon }\end{array}$ & 78,00 & 65,70 & - & 17,50 & - & 3,50 & - \\
\hline $\begin{array}{l}090 \\
\text { Hulu } \\
\text { Sihapas } \\
\end{array}$ & 85,10 & 4,70 & - & - & 20 & - & - \\
\hline $\begin{array}{l}\text { Kab Padang } \\
\text { Lawas } \\
\text { Utara }\end{array}$ & $\begin{array}{c}1 \\
346,35\end{array}$ & 578,30 & 0,70 & 514,60 & 260,90 & 352,40 & - \\
\hline 2014 & 17115 & $\begin{array}{c}4 \\
774,00\end{array}$ & - & 10019,00 & 3765,00 & - & - \\
\hline
\end{tabular}




\section{JESYA}

JURNAL EKONOMI \& EKONOMI SYARIAH

Jurnal Ekonomi \& Ekonomi Syariah Vol 3 No 2, Juni 2020

E-ISSN : 2599-3410 |P-ISSN : 2614-3259

DOI : https://doi.org/10.36778/jesya.v3i2.185

5592,26

2542,70

116,31

\section{METODOLOGI PENELITIAN}

\section{Lokasi Penelitian}

Penelitian ini dilakukan di Kab. Padang Lawas Utara Propinsi Sumatera Utara. Alasannya adalah:

1. Pertanian di kab. Padang Lawas Utara merupakan mata pencaharian yang utama bagi masyarakat di Kab. Padang Lawas Utara dan juga diharapkan menjadi pertanian terpadu yang melakukan pengembangan terhadap kegiatan ekonomi masyarakat.

2. Pertanian di kab. Padang Lawas Utara ini merupakan pertanian yang memadukan antara lahan pertanian dan perkebunan, hasil pertanian dan limbah dari pertanian tersebut diharapkan dapat dimanfaatkan kepada kegiatan pertanian yang ada di masyarakat.

\section{B. Pendekatan Penelitian}

Penelitian tentang model pemberdayaan ekonomi masyarakat di Kab, Padang Lawas Utara ini diarahkan pada pendekatan deskriptif kualitatif. Alasannya adalah pertama, menyesuaikan metode kualitatif lebih mudah apabila berhadapan dengan kenyataan jamak. Kedua, metode ini menyajikan secara langsung hakikat hubungan antara peneliti dengan responden. Ketiga, metode ini lebih peka dan lebih dapat menyesuaikan diri dengan banyak penajaman pengaruh bersama terhadap pola-pola nilai yang dihadapi. Keempat, metode ini lebih mudah untuk menjawab pertanyaan penelitian. Dalam hal ini terdapat beberapa dimensi penelitian.

\section{HASIL PENELITIAN}

Menurut Ife pengembangan ekonomi masyarakat merupakan upaya merelokasikan aktivitas ekonomi dalam masyarakat agar dapat mendatangkan keuntungan bagi masyarakat dan untuk merevitalisasi masyarakat lokal serta untuk memperbaiki kualitas kehidupan. Sedangkan menurut Zubaedi pengembangan ekonomi masyarakat adalah suatu cara yang memungkinkan setiap orang dapat meningkatkan kualitas hidupnya serta mampu memperbesar pengaruhnya terhadap proses-proses yang mempengaruhi kehidupannya.

Dari beberapa pendapat di atas dapat disimpulkan bahwa pengembangan ekonomi masyarakat adalah suatu cara yang dilakukan oleh masyarakat, dengan dukungan atau tanpa dukungan pihak luar, untuk memperbaiki kehidupannya yang berbasis pada kemampuan mereka sendiri, melalui upaya optimalisasi kemampuan serta menghindari "rekayasa" pihak luar yang sering mematikan kemandirian masyarakat. Pengembangan ekonomi masyarakat ini memiliki kesamaan dengan tujuan dari pertanian terpadu yaitu:

1) Memasyarakatkan sistem pertanian terpadu sebagai pertanian yang lestari dimana lokasi tanah diperhatikan dan ditingkatkan untuk menjamin kelangsungan siklus yang berkesinambungan.

2) Membentuk masyarakat tani yang mandiri dan peduli lingkungan dan sadar akan jati dirinya sebagai penjaga alam.

3) Meningkatkan taraf hidup kesejahteraan masyarakat yang adil dan merata dengan pola pikir maju dan pola hidup sederhana.

4) Membentuk suatu ikatan kerjasama dalam bentuk pertanian inti rakyat serta membangun kerjasama yang sejajar dalam memenuhi kebutuhan sektor pertanian.

5) Memenuhi kebutuhan pasar akan makanan yang sehat dan bebas polusi guna meningkatkan kualitas dalam persaingan.

Hasil pengembangan ekonomi masyarakat biasanya bisa dilihat dari situasi dan kondisi masyarakat sekitar setelah pelaksanaan pertanian terpadu tersebut. Dalam hal ini beberapa elemen 


\section{JESYA}

JURNAL EKONOMI \& EKONOMI SYARIAH

Jurnal Ekonomi \& Ekonomi Syariah Vol 3 No 2, Juni 2020

E-ISSN : 2599-3410 |P-ISSN : 2614-3259

DOI : https://doi.org/10.36778/jesya.v3i2.185

sangat menentukan, dari konsep pengembangan ekonomi masyarakat yaitu filosopi, tujuan, model, dan strategi pengembangan ekonomi masyarakat, Sehingga hasil dari pengembangan ekonomi masyarakat tersebut dapat menciptakan :

1. Terwujudnya lapangan pekerjaan.

2. Tumbuhnya kemandirian.

3. Meningkatkan ekonomi masyarakat.

Hasil pengembangan ekonomi masyarakat melalui pertanian terpadu yang dimaksud dalam penelitian ini adalah meningkatnya pendapatan masyarakat, mampu menciptakan lapangan pekerjaan bagi masyarakat itu sendiri sehingga terwujudnya kemandirian.Terdapat beberapa konsep dalam pengembangan Ekonomi Masyarakat melalui sektor pertanian:

1. FilosofiPengembanganEkonomiMasyarakat

2. Tujuan Pengembangan Ekonomi Masyarakat

3. Model Pengembangan Ekonomi Masyarakat

4. Strategi PengembanganEkonomiMasyarakat

Dalam hal ini kegiatan pengembangan ekonomi masyarakat melalui sektor pertanian dapat dicapai dengan beberapa konsep diatas yang juga memadukan dengan kebutuhan dan keadaan yang ada dilokasi.

\section{a. Implementasi pengembangan ekonomi masyarakat melalui sektor pertanian}

Dalam melakukan kegiatan perekonomian masyarakat haruslah dapat diterapkan implementasi yaitu berupa pelaksanaan atau penerapan, implementasi pengembangan ekonomi masyarakat melalui pertanian terpadu diantaranya adalah:

1. Pembenihan varietas-varietas pertanian yang selalu dapat memberikan manfaat bagi perekonomian masyarakat.

2. Pemanfaatan limbah menjadi pupuk.

3. Penanaman padi, sayuran dan buah- buahan.

4. Peternakan, dan

5. Adanya perkumpulan petani (masyarakat) setiap hari minggu.

Implementasi pengembangan ekonomi masyarakat yang dimaksud dalam penelitian ini adalah melaksanakan kegiatan pertanian terpadu dengan ke lima point di atas.

\section{b. Hasil Pengembangan Ekonomi Masyarakat melalui sektor pertanian.}

Hasil pengembangan ekonomi masyarakat biasanya bisa dilihat dari situasi dan kondisi masyarakat sekitar setelah pelaksanaan pada sektor pertanian tersebut. Terdapat beberapa elemen sangat menentukan dari konsep pengembangan ekonomi masyarakat yaitu filosopi, tujuan, model, dan strategi pengembangan ekonomi masyarakat. Hasil pengembangan ekonomi masyarakat melalui pertanian terpadu yang dimaksud dalam penelitian ini adalah meningkatnya pendapatan masyarakat, mampu menciptakan lapangan pekerjaan bagi masyarakat itu sendiri sehingga terwujudnya kemandirian sesuai dengan indikator di atas.

\section{KESIMPULAN}




\section{JESYA}

JURNAL EKONOMI \& EKONOMI SYARIAH

Jurnal Ekonomi \& Ekonomi Syariah Vol 3 No 2, Juni 2020

E-ISSN : 2599-3410 |P-ISSN : 2614-3259

DOI : https://doi.org/10.36778/jesya.v3i2.185

Berdasarkan pemaparan di atas maka penulis dapat menyimpulkan sebagai berikut:

1. Konsep pengembangan ekonomi masyarakat melalui sektor pertanian yang pertama filosofi pengembangan ekonomi masyarakat bahwa sektor pertanian ini merupakan salah satu sumber pendapatan yang ada di Kab. Padang Lawas Utara ;

2. Adapun tujuannya adalah untuk melestarikan tanaman, meningkatkan pendapatan masyarakat, memandirikan masyarakat, dan pemberdayaan SDM masyarakat. modelnya adalah stimulan dari pemerintah Kabupaten dengan bantuan dana untuk pembuatan Agrowisata dan swadaya masyarakat, selain itu melakukan pelatihan dengan teori $35 \%$ dan praktek $65 \%$. Keempat, strateginya yaitu melalui tehnologi di Indonesia maupun Luar Negeri, menjalin kemitraan dengan instansi pemerintah, untuk mendapatkan informasi terkait pertanian dari lembaga pertanian yang modern dan profesional;

3. Implementasi sektor pertanian di kab. Padang Lawas Utara sudah bagus karena kegiatan pertanian disana saling berkesinambungan. Hal ini terlihat dengan adanya beberapa rantai kegiatan linier yaitu ada berjalannya sektor pertanian dan peternakan yang baik.

Hasil dari pengembangan ekonomi masyrakat melalui pertanian terpadu ini sudah dapat meningkatkan pendapatan ekonomi masyarakat tetapi masih mengarah pada kesejahteraan, menjadi lapangan pekerjaan bagi masyarakat dan memandirikan masyarakat. Akan tetapi masih memerlukan penyehatan dan efektivitas pada bidang perawatan dan pengolahan dari hasil pertanian tersebut.

\section{DAFTAR PUSTAKA}

Agustira, M. Akmal dan Amalia, R. 2012. Kendala Peningkatan Produktivitas Pada Perkebunan Kelapa Sawit Rakyat di Indonesia. Warta Pusat Penelitian Kelapa Sawit Vol 17 No. 1 Hal. 21- 29. Pusat Penelitian Kelapa Sawit, Medan.

Amirin, Tatang M. 2011. Populasi dan Sampel Penelitian 4: Ukuran sampel Slovin. Tatangmanguny.wordpress.com.

Badan Pusat Statistik Kabupaten Padang Lawas Utara, 2015.

Bappenas, Perkembangan Ekonomi Indonesia dan Dunia Triwulan IV, Kedeputian Bidang Ekonomi Kementerian PPN/BAPPENAS, 2019.

Bone, L. E. 2002. Pengantar Bisnis. Jakarta: Edisi 1,Terjemahan adriansyah Anwar, Emil Salim, Kusnedi, Erlangga, Jilid 2.

Hutajalu, D. Melani, M. Nasir, dan Arwansyah. 2018. Analysis of the Leading Sector and the Effect of the Economic Growth: a case studi in Pakpak Barat regency, Indonesia. Studia Universitatis "Vasile Goldis" Arab. Economics Series Vol 28: 37-49

Daim, C. 2003. Pengembangan Kemitraan dan Dukungan Pendanaannya di Bidang Perkebunan. Bogor: IPB.

Daniel, M. 2001. Pengantar Ekonomi Pertanian. Jakarta: Bumi Aksara. .2002. Pengantar Ilmu Pertanian. Jakarta: PT. Bumi Aksara.

Gevisioner, Rudi Febriamansyah, Ifdal dan Suardi Tarumun, "Kegagalan Membangun Pertanian Meningkatkan Kesejahteraan Petani di Indonesia, Prosiding Seminar Nasional 
Perencanaan Pembangunan Inklusif Desa Kota, 2017.

Riska Novitasari, Lies Sulistyowati dan Maman H. Karmana.” Analisis Potensi Ekonomi Dalam Pembangunan Pertanian Kabupaten/ Kota Di Propinsi Jawa Barat: Mimbar Agribisnis, 2019

Totok Mardikanto dan Poerwoko Soebiato.Pemberdayaan Masyarakat Perspektif Kebijakan Publik. Bandung : Alfabeta. 2012. 